\title{
Pembelajaran Problem based learning Terhadap Berpikir Kritis Peserta Didik Sekolah Dasar
}

\author{
Muhammad Setyawan ${ }^{1}$, Henny Dewi Koeswanti ${ }^{2}$
}

1,2 Jurusan Pendidikan Guru Sekolah Dasar, Universitas Kriten Satya Wacana, Salatiga, Indonesia

\section{A R T I C LE I N F O}

Article history:

Received August 09, 2021

Revised August 15, 2021

Accepted September 30, 2021

Available online October 25, 2021

Kata Kunci:

Problem Based Learning, Berpikir Kritis

Keywords:

Problem Based Learning, Critical Thinking

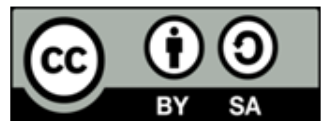

This is an open access article under the CC BY-SA license.

Copyright $(\subset 2021$ by Author. Published by Universitas Pendidikan Ganesha.

\begin{abstract}
A B S T R A K
Banyaknya peserta didik mendapatkan hasil belajar kurang memuaskan. hal tersebut disebabkan karena kurangnya berpikir kritis siswa dalam memecahkan masalah dalam suatu pembelajarn. Penelitian ini memiliki tujuan untuk menganalisis model pembelajaran Problem based learning dalam meningkatkan berpikir kritis peserta didik sekolah dasar. Metode yang digunakan dalam penelitian ini yaitu metode meta analisis. Tahap penelitian diawali dengan mencari topik yang relevan guna memudahkan dalam mengumpulkan data. Data tersebut diperoleh dengan cara menelusuri jurnaljurnal online melalui google scolaria dengan kata kunci Problem based learning, Meningkatkan Berpikir Kritis, Sekolah Dasar. Dari penelusuran yang dilakukan diperoleh 25 artikel tetapi yang relevan untuk digunakam hanya 12 artikel. Data-data yang telah diperoleh diolah kembali menggunakan metode kuantitatif. Berdasarkan hasil analisis penggunaan model pembelajaran Problem based learning dalam pembelajaran terbukti dapat meningkatkan Motivasi Belajar Peserta Didik paling rendah $5,28 \%$ dan yang paling tinggi 99,47\%. Penggunaan Problem based learning sangat berpengaruh terhadap berpikir kritis peserta didik. Selain itu peserta didik juga mempunyai pengalaman yang berbeda dalam proses pembelajaran karena dituntut untuk memecahkan permasalahan dalam suatu proses pembelajaran. implikasi penelitian ini diharapkan guru-guru dapat menggunakan model pembelajaran ini pada proses pembelajaran. sehingga meningkatkan kemampuan siswa dalam memahami materi pelajaran dengan mudah selama proses pembelajaran.
\end{abstract}

\section{A B S T R A C T}

The number of students get unsatisfactory learning outcomes. this is due to the lack of students' critical thinking in solving problems in a learning. This study aims to analyze the problem-based learning model in improving critical thinking of elementary school students. The method used in this study is the meta-analysis method. The research phase begins with finding relevant topics to make it easier to collect data. The data was obtained by searching online journals through google scolaria with the keywords Problem based learning, Improving Critical Thinking, Elementary School. From the search conducted, 25 articles were obtained, but only 12 articles were relevant for use. The data that has been obtained is reprocessed using quantitative methods. Based on the results of the analysis of the use of the Problem based learning model in learning, it is proven that it can increase the students' learning motivation, the lowest is $5.28 \%$ and the highest is $99.47 \%$. The use of problem based learning is very influential on the critical thinking of students. In addition, students also have different experiences in the learning process because they are required to solve problems in a learning process. The implication of this research is that it is hoped that teachers can use this learning model in the learning process. thereby increasing students' ability to understand the subject matter easily during the learning process.

\section{PENDAHULUAN}

Berpikir kritis adalah suatu proses berpikir yang bertujuan untuk membuat keputusan yang rasional serta diarahkan dalam melakukan sesuatu(Ariani, 2020; Astiwi et al., 2020). Berpikir kritis adalah sebuah proses terorganisasi yang memungkinkan peserta didik untuk mengevaluasi bukti, asumsi, logika dan bahasa yang mendasari pernyataan orang lain (Afifah et al., 2019; Febrina \& Airlanda, 2020). Berpikir kritis mencakup strategi kognitif tingkat tingi seperti membandingkan situasi, menjelaskan masalah dan hasil, mengembangkan kriteria untuk evaluasi, menggunakan sumber informasi, menghasilkan solusi, menganalisis dan membangun 
hubungan(Ihsan et al., 2019; Pitt et al., 2015; Polat \& Aydın, 2020; Sudarti \& Putra, 2015). Berpikir kritis memungkinkan seseorang untuk dapat mempelajari persoalan secara sistematis dan dapat menemukan solusi untuk menyelesaikannya (Al-Fikry et al., 2018; Qurniati et al., 2015; Suci et al., 2019). Berpikir kritis berlaku apabila siswa mampu menguji pengalamannya, mengevaluasi kemampuan, ide-ide, dan mempertimbangkan argumen. Kemampuan berpikir kritis adalah kemampuan berpikir tingkat tinggi dalam memecahkan suatu masalah secara rasional (Afriansyah et al., 2020; Triana et al., 2020). Untuk mengembangkan keterampilan berpikir kritis Peserta didik harus dilibatkan secara langsung dalam proses pembelajaran (Boso et al., 2021). Pentingnya penanaman keterampilan berpikir kritis untuk memecahkan dan mengendalikan masalah sosial yang terjadi dengan cara mampu membuat konsep, menganalisis dan memecahkan masalah (Tapung et al., 2018). Kemampuan berpikir kritis sangat penting bagi peserta didik hal ini karena berpikir kritis berhubungan erat dengan kesadaran peserta didik untuk menyelesaikan sebuah masalah yang diberikan (Crismono, 2017; Ikhsan et al., 2017). Kemampuan perpikir kritis juga dapat membiasakan siswa untuk berpikir lebih rasional dalam menentukan dan memilih alternatif pilihan yang terbaik (Firdaus et al., 2019). Jabaran tersebut memberikan gambaran yang jelas pentingnya kemampuan berpikir kritis bagi peserta didik.

Saat ini kita sedang dihadapkan dengan suatu masalah, berpikir kritis dapat membantu kita untuk lebih tenang dalam membedakan fakta dan opini (Afifah et al., 2019; Ikhsan et al., 2017; Wedekaningsih et al., 2019). Dengan demikian kita bisa mengambil keputusan dengan tepat sehingga dapat menyelesaikan masalah tersebut. Pada saat ini SD ini sudah melaksanakan kurikulum 2013, akan tetapi dalam pembelajaran belum sepenuhnya menerapkan sintaks pembelajaran kurikulum 2013, dan pembelajaran masih didominasi pada aktivitas guru dan pada masa pandemi ini siswa sangat sulit dalam menerima pembelajaran secara langsung guru sangat sulit dalam memberikan materi pembelajaran kesiswa yang membuat siswa sulit dalam menangkap pembelajaran hari itu juga (Mulyadin, 2016; Novika Auliyana et al., 2018; Persada et al., 2020). Misalnya guru belum sepenuhnya menggunakan model-model pembelajaran yang inovatif, guru hanya menggunakan model pembelajaran sistem ceramah sebagai penunjang pembelajaran, peserta didik diberikan suatu permasalah, kemudian berdiskusi dengan orang tuanya setalah itu dikumpulkan, sehingga menjadikan peserta didik kurang begitu aktif dalam pembelajaran dan cenderung saat mengerjakan tugas siswa sering dikerjakan oleh orang tuanya (Alita et al., 2019; Bosica, S.Pyper, \& MacGregor, 2021; Suari, 2018). Melalui hasil pengamatan juga terlihat peserta didik terkesan kurang mampu mengembangkan kemampuan berpikirnya dan tingkat kemampuan berpikir peserta didik hanya sampai pada tingkat memahami saja. Salah satu pembelajaran yang mampu melibatkan peserta didik dalam aktivitas pembelajaran dan mampu meningkatkan kemampuan berpikir kritis peserta didik.

Solusi yang dapat dilakukan untuk mengatasi permasalahan tersebut yaitu dengan menerapkan model pembelajaran. salah satu model pembelajaran yang dapat diterapkan yaitu model pembelajaran problem-based learning. Model pembelajaran Problem based learning yang dimaksud adalah proses kegiatan belajar mengajar yang memberikan masalah kepada siswa dan harapannya siswa sebagai subjek belajar dapat menyelesaikan masalah yang diberikan guru dengan melakukan kegiatan pembelajaran yang aktif dan guru hanya sebagai fasilitator (HS et al., 2019; Seibert, 2020; Utama \& Kristin, 2020). Salah satu model pembelajaran yang dapat digunakan guna menunjang pembelajaran yang inovatif yaitu Problem based learning. Model pembelajaran yang dapat digunakan guru adalah model Problem based learning (PBL). Model ini merangsang siswa untuk dapat menyelesaikan masalah yang diberikan oleh guru (Kristiana \& Radia, 2021; Saidah et al., 2014). Problem based learning adalah pendekatan yang memakai permasalahan dunia nyata sebagai suatu kontek, sebagai rangsangan kemampuan berpikir kritis serta kemampuan pemecahan masalah siswa dalam memahami konsep dan prinsip yang esensi dari suatu mata pelajaran (Al-Fikry et al., 2018; Farisi et al., 2017; D. Utami, 2019). Konsep dalam PBL, pembelajaran akan tercapai jika dalam proses pembelajaran dipusatkan pada tugas-tugas atau permasalahan sebagai tumpuan dalam pembelajaran, mahasiswa di dorong untuk mencari informasi yang di butuhkan dalam menyelesaikan masalah dengan mengidentifikasi pokok bahasan (issue) untuk mengembangkan pemahaman tentang berbagai konsep yang mendasari masalah tadi serta prinsip pengetahuan lainnya yang relevan (Halidayanti, 2016; Prasetyo, 2018).

Beberapa temuan penelitian sebelumnya menyatakan model pembelajaran problem based learning dapat menstimulasi kemampuan berpikir kritis melalui proses pembelajaran berbasis masalah (Stephani, 2017). model pembelajaran Problem based learning dapat meningkatkan keterampilan berpikir kritis dan mata pelajaran matematika (Sari et al., 2019). Selain itu model Problem based learning memberikan pengaruh yang besar dalam meningkatkan hasil belajar siswa (Pangesti \& Radia, 2021; Utama \& Kristin, 2020). proses berpikir kritis dalam suatu forum merupakan suatu hal yang penting. Oleh karena itu, berpikir kritis sering kali menjadi tujuan dan hasil utama dari suatu proses pendidikan. Dari kajian sebelumnya penelitian ini memilih penelitian meta analisis yang menggunakan sumber-sumber penelitian relevan yang sudah ada guna mengetahui dampak penerapan Problem based learning dalam meningkatkan berpikir kritis peserta didik sekolah dasar. Tujuan penelitian ini menganalisis penerapan pembelajaran problem-based learning terhadap berpikir kritis peserta didik Sekolah Dasar. 


\section{METODE}

Penelitian yang digunakan dalam penelitian ini adalah meta analisis, analisis yang menguraikan sistematik yang mengaanalisis hasil penelitian yang sudah diterbitkan secara nasional yang berkaitan dengan Penerapan model pembelajaran Problem based learning memiliki pengaruh terhadap Berpikir Kritis peserta didik.". Hal ini dilakukan untuk memberikan kajian keajegan atau tidaknya pada sebuah penelitian yang sudah dilakukan. Data penelitian yang akan dikumpulkan dengan cara pencarian artikel atau jurnal ilmiah di google scholaria atau google cendekia. Berdasarkan penelusuran didapat 25 artikel yang sesuai dengan judul yang akan diteliti dan dipilih 12 yang relevan. Naskah yang dikaji merupakan hasil dari penelitian Eksperimen sehingga memiliki data nilai sebelum dan sesudah perlakuan. Teknik analisis dengan menggunakan metode pembandingan untuk mengetahui dampak penggunaan model pembelajaran Problem based learning berbasis selisih skor berpikir kritis peserta didik sebelum dan sesudah tindakan.

\section{HASIL DAN PEMBAHASAN}

Hasil

Penelitian yang bertujuan mengkaji efektivitas model pembelajaran problem-based learning (PBL) terhadap berpikir kritis siswa melalui kajian meta analisis. Penelitian ini membandingkan 12 artikel yang sudah memenuhi syarat. Hasil perbandingan artikel-artikel yang digunakan sebagai sampel penelitian ini ditunjukkan pada tabel 1 berikut.

Tabel 1. Peningkatan Berpikir Kritis

\begin{tabular}{|c|c|c|c|c|c|c|}
\hline \multirow{2}{*}{ No } & \multirow{2}{*}{ Topik Penelitian } & \multirow{2}{*}{ Peneliti } & \multicolumn{4}{|c|}{ Peningkatan Hasil Belajar } \\
\hline & & & Sebelum & Sesudah & Gain & Gain\% \\
\hline 1. & $\begin{array}{l}\text { Penerapan Problem based } \\
\text { learning dalam Pembelajaran } \\
\text { Tematik Integratif untuk } \\
\text { Meningkatkan Kemampuan } \\
\text { Berpikir Kritis Siswa Kelas III } \\
\text { sekolah Dasar }\end{array}$ & $\begin{array}{l}\text { (Lisbiyaningrum \& } \\
\text { Wulandari, 2019) }\end{array}$ & 62,5 & 84,3 & 21,8 & 34,88 \\
\hline 2. & $\begin{array}{l}\text { Penerapan Model } \\
\text { Pembelajaran problem based } \\
\text { learning untuk Meningkatkan } \\
\text { Kemampuan Berpikir Kritis } \\
\text { dan Hasil Belajar Matematika } \\
\text { Siswa Kelas 4 SD }\end{array}$ & $\begin{array}{c}\text { (Asriningtyas et al., } \\
\text { 2018) }\end{array}$ & 69,44 & 88,89 & 19,45 & 28,00 \\
\hline 3. & $\begin{array}{l}\text { Penerapan Model } \\
\text { Pembelajaran Problem based } \\
\text { learning Untuk Meningkatkan } \\
\text { Hasil Belajar Matematika dan } \\
\text { berpikir Kritis Siswa Kelas } 4 \\
\text { SD }\end{array}$ & $\begin{array}{l}\text { (N. B. Utami et al., } \\
\text { 2019)Niken Bekti } \\
\text { Utami (2019) }\end{array}$ & 58,92 & 80,28 & 21,36 & 36,25 \\
\hline 4. & $\begin{array}{l}\text { Upaya Peningkatan } \\
\text { Kemampuan Berpikir Kritis } \\
\text { Hasil Belajar Tematik Melalui } \\
\text { Model Problem based learning } \\
\text { (PBL) Kelas V SD }\end{array}$ & $\begin{array}{l}\text { (Purnaningsih et al., } \\
\text { 2019) }\end{array}$ & 58,57 & 82,68 & 24,11 & 41,16 \\
\hline 5. & $\begin{array}{l}\text { Penerapan Problem based } \\
\text { learning untuk Meningkatkan } \\
\text { Kemampuan Berpikir Kritis } \\
\text { dan Hasil Belajar Siswa Kelas } \\
\text { III }\end{array}$ & (Ningsih et al., 2018) & 63,49 & 84,12 & 20,63 & 32,49 \\
\hline 6. & $\begin{array}{l}\text { Penerapan Model } \\
\text { Pembelajaran Problem based } \\
\text { learning untuk Meningkatkan } \\
\text { Kemampuan Berpikir Kritis } \\
\text { Siswa Kelas } 3 \text { Sekolah Dasar }\end{array}$ & $\begin{array}{c}\text { Devri Yunia } \\
\text { Styaningrum (2018) }\end{array}$ & 75,86 & 82,76 & 6,9 & 9,09 \\
\hline 7. & $\begin{array}{l}\text { Keefektifan Model } \\
\text { Pembelajaran Problem based } \\
\text { learning dan Problem Solving }\end{array}$ & $\begin{array}{c}\text { (Prayoga \& } \\
\text { Setyaningtyas, 2021) }\end{array}$ & 69,60 & 87,35 & 17,75 & 25,50 \\
\hline
\end{tabular}


Terhadap Kemampuan

Berpikir Kritis Matematika

Siswa Kelas V

8. Penerapan Model Problem

based learning untuk

$\begin{array}{lllll}\text { (Wati et al., 2017) } \quad 40,02 & 79,83 & 39,81 & 99,47\end{array}$

Meningkatkan hasil Belajar

dan Ketrampilan Berpikir

Kritis Peserta Didik pada

materi larutan Penyangga

9. Efektivitas Model

Pembelajaran Problem based

(R. A. Utami \& Giarti, 2020)

learning (PBL) dan Dicovery

Learning ditinjau dari

Ketrampilan Berpikir Kritis

Siswa Kelas 5

10. Penerapan Model PBL Untuk

Meningkatkan Kemampuan

Berpikir Kritis Siswa Pada

Kelas IV Sekolah Dasar

11. Pengaruh Model Pembelajaran

Problem BasedLearning

Terhadap Kemampuan

Berpikir Kritis di Sekolah

Dasar

12. Penerapan Model Problem

based learning untuk

Meningkatkan Berpikir Kritis

Siswa Kelas 5 pada Mata

Pelajaran PKN di SD

Muhammadiyah Kauman

Tahun 2016/2017
(Septiana \&

Kurniawan, 2018)

Rata-rata Pembelajaran Menggunakan Problem based learning

$\begin{array}{lllll}\begin{array}{l}\text { (Kartikasari et al., } \\ \text { 2021) }\end{array} & 62,14 & 71,40 & 9,26 & 14,90 \\ & & & & \\ \text { (Rahmatia, 2020) } & 57,07 & 64,14 & 7,07 & 12,38\end{array}$

77,59

81,74

4,1

5,28

12,38

51,61

70,96

19,35

37,49

Dari 12 sampel artikel jurnal menunjukkan besarnya pengaruh penggunaan model pembelajaran Problem based learning terhadap Berpikir kritis peserta didik. Berdasarkan data yang terdapat pada tabel 1 ternyata penggunaan model pembelajaran Problem based learning mampu meningkatkan Berpikir kritis peserta didik. Dari tabel di atas dapat dilihat adanya peningkatan Berpikir kritis peserta didik mulai dari yang terendah 5,28\% sampai yang tertinggi 99,47\%. Berdasarkan hasil analisis data pada tabel 1 rata-rata skor sebelum tindakan yaitu 62,23. Sedangkan rata-rata skor setelah tindakan yaitu 79,63. Selisih rata-rata skor sebelum dan sesudah tindakan yaitu 17,63. Dari data pada tabel 1 dapat dilihat rata-rata gain\% yaitu 31,40\%. Penggunaan model pembelajaran Problem based learning dapat menjadi solusi efektif yang dapat digunakan guru untuk meningkatkan berpikir kritis peserta didik.

Penggunaan model pembelajaran Problem based learning dapat menjadi solusi efektif yang dapat membuat peserta didik lebih aktif dalam mengikuti pembelajaran di kelas dan meningkatkan Berpikir kritis peserta didik. Berpikir kritis peserta didik yang tinggi dapat membuat peserta didik mampu memecahkan masalah dalam pembelajaran serta tercipta suasana kelas yang kondusif dan interaktif selama proses pembelajaran berlangsung. siswa dapat diartikan bisa dituntut untuk berfikir secara kritis agar dapat mencari atau menemukan jawaban sendiri tentang permasalahannya sehingga memacu siswa untuk berpikir kritis. Hal tersebut dapat membantu berpikir kritis dan mendorong peserta didik untuk belajar dengan giat sehingga memperoleh hasil yang maksimal. Hal tersebut diperkuat dengan penelitian sebelumnya yang menyatakan bahwa model Problem based learning merupakan model pembelajaran yang dikembangkan guna membantu para guru mengembangkan kemampuan berfikir dan keterampilan memecahkan masalah pada peserta didik selama mereka mempelajari materi pembelajaran (S.Pyper, \& MacGregor, 2021; Rosa \& Pujiati, 2017). Problem based learning yang melibatkan peserta didik dalam belajar baik secara individual maupun kolaborasi serta mampu melakukan pemecahan masalah sehari-hari melalui proses pembelajaran (Rahmatia, 2020; Suriana et al., 2016). Oleh karena itu, model ini sangat efektif untuk meningkatkan kemampuan siswa dalam memecahkan permasalahan kehidupan sehari-hari.

Penerapan model PBL dapat memperbaiki kemampuan pemecahan masalah siswa, sehingga siswa dapat menilai kemampuannya sendiri dalam memecahkan masalah menjadi lebih baik karena pada model PBL ini 
siswa harus mencari solusi dan mereka juga akan dilatih untuk memecahkan masalah, dimana masalah yang dihadirkan dalam proses pembelajaran mencerminkan masalah nyata yang dihadapi dalam kehidupan seharihari. Penerapan $\mathrm{PjBL}$ dalam proses pembelajaran memberikan siswa kesempatan untuk mengeksplor kemampuannya dalam hal berpikir kritis, pemecahan masalah, dan juga kerja mandiri (Asriningtyas et al., 2018; Lidyawati et al., 2017). Kemampuan berpikir kritis yaitu kemampuan berpikir yang dimilik peserta didik untuk membandingkan dua atau lebih informasi untuk tujuan memperoleh pengetahuan lebih melalui pengujian terhadap gejala-gejala menyimpang dan kebenaran ilmiah. Salah satu tujuan dari pendidikan yaitu terbentuk peserta didik yang bersemangat untuk terus belajar (Ariani, 2020; Prayoga \& Setyaningtyas, 2021; Sari et al., 2019). Berpikir kritis memiliki peranan yang sangat penting dalam pencapaian peserta didik. Peserta didik dengan memecahkan masalah dengan berpikir kritis dalam belajar akan lebih terlibat aktif selama proses pembelajaran dan berhasil dalam belajar(Rahmatia, 2020; Saputro \& Rayahu, 2020; Septiana \& Kurniawan, 2018). Keterampilan berpikir kritis perlu dibiasakan dalam proses pembelajaran sehingga peserta didik memiliki kemampuan menyelesaikan permasalahan yang dihadapi. Oleh karena itu, meningkatkan kemampuan pemecahan masalah siswa sangatlah penting dalam pembelajaran agar tercapai tujuan pembelajaran dengan baik.

Temuan ini diperkuat dengan temuan penelitian sebelumnya yang menyatakan model Problem based learning mampu meningkatkan hasil belajar bagi siswa sekolah dasar (Lidyawati et al., 2017; Sipayung \& Hutahaean, 2016). Sejalan dengan penelitian yang dilakukan oleh (Lindayani, 2017) yang menunjukkan bahwa penerapan model Problem based learning dapat meningkatkan hasil belajar IPA pada peserta didik. Kemampuan pemecaahan masalah siswa yang diajarkan dengan model PBL lebih baik daripada siswa yang diajarkan dengan pembelajaran konvensional (Saputro \& Rayahu, 2020; R. A. Utami \& Giarti, 2020). Model pembelajaran problem based learning dapat merangsang kemampuan siswa untuk berpikir kritis (Al-Fikry et al., 2018; Lidyawati et al., 2017; Rahmatia, 2020). Dari pembahasan tersebut model pembelajaran problem based learning dapat meningkatkan kemampuan berpikir kritis siswa. Sehingga model ini efektif dan dapat diterapkan pada proses pembelajaran. implikasi penelitian ini diharapkan guru-guru dapat menggunakan model pembelajaran ini pada proses pembelajaran. sehingga meningkatkan kemampuan siswa dalam memahami materi pelajaran dengan mudah selama proses pembelajaran

\section{SIMPULAN}

Berdasarkan hasil penelitian meta analisis di atas, dapat ditarik simpulan bahwa model pembelajaran Problem based learning dapat meningkatkan Berpikir kritis peserta didik sekolah dasar. Adanya peningkatan berpikir kritis peserta didik mulai dari yang terendah sampai yang tertinggi. Selain itu dapat juga dilihat dari adanya kenaikan rata-rata skor sebelum tindakan dan rata- rata skor setelah tindakan. Hasil penelitian ini merekomendasikan agar guru menggunakan pembelajaran PBL untuk mengembangkan kemampuan berpikir kritis siswa dalam pembelajaran. Namun, guru juga harus memastikan sarana dan prasarana yang akan digunakan saat pembelajaran tersedia dengan baik dan stabil baik untuk siswa maupun untuk guru sendiri. Serta guru juga harus memperhatikan kondisi kelas pada saat pembelajaran

\section{DAFTAR PUSTAKA}

Afifah, E. P., Wahyudi, \& Setiawan, Y. (2019). Efektivitas Problem Based Learning Dan Problem Solving Terhadap Kemampuan Berpikir Kritis Siswa Kelas V Dalam Pembelajaran Matematika. Journal of Mathematics Education, Science and Technology, 4(1), 95-107. https://doi.org/10.30651/must.v4i1.2822.

Afriansyah, E. A., Herman, T., \& Dahlan, J. A. (2020). Mendesain Soal Berbasis Masalah untuk Kemampuan Berpikir Kritis Matematis Calon Guru. Mosharafa: Jurnal Pendidikan Matematika, 9(2), $239-250$. https://doi.org/10.31980/mosharafa.v9i2.649.

Al-Fikry, I., Yusrizal, Y., \& Syukri, M. (2018). Pengaruh Model Problem Based Learning Terhadap Kemampuan Berpikir Kritis Peserta Didik Pada Materi Kalor. Jurnal Pendidikan Sains Indonesia, 6(1), 17-23. https://doi.org/10.24815/jpsi.v6i1.10776.

Alita, K. U., Koeswanti, H. D., \& Giarti, S. (2019). Penerapan Model Problem Based Learning Untuk Meningkatkan Kemampuan Berpikir Kritis Siswa Kelas V Sdn Ledok 5 Tahun Pelajaran 2018/2019. Jurnal Basicedu, 3(1), 169 - 173. https://doi.org/10.31004/basicedu.v3i1.97.

Ariani, T. (2020). Analysis of Students' Critical Thinking Skills in Physics Problems. Physics Educational Journal, 3(1), 1-13. https://doi.org/10.37891/kpej.v3i1.119.

Asriningtyas, A., Kristin, F., \& Anugraheni, I. (2018). Penerapan Model Pembelajaran Problem Based Learning Untuk Meningkatkan Kemampuan Berpikir Kritis Dan Hasil Belajar Matematika Siswa Kelas 4 SD. Jurnal Karya Pendidikan Matematika, 5(1), 23-32. https://doi.org/10.26714/jkpm.5.1.2018.23-32.

Astiwi, Tri, K. P., Antara, P. A., \& Agustiana, I. G. A. T. (2020). Pengembangan Instrumen Penilaian Kemampuan Berpikir Kritis Siswa SD Pada Mata Pelajaran PPKn. Jurnal Ilmiah Pendidikan Profesi Guru, 3(3). 
Bosica, J., S.Pyper, J., \& MacGregor, S. (2021). Incorporating problem-based learning in a secondary school mathematics preservice teacher education course. Teaching and Teacher Education, 102, 103335. https://doi.org/10.1016/j.tate.2021.103335.

Bosica, J., S.Pyper, J., \& Stephen MacGregor. (2021). Incorporating problem-based learning in a secondary school mathematics preservice teacher education course. Teaching and Teacher Education, 102, 103335. https://doi.org/10.1016/j.tate.2021.103335.

Boso, C. M., van der Merwe, A. S., \& Gross, J. (2021). Students' and Educators' Experiences with Instructional Activities Towards Critical Thinking Skills Acquisition in a Nursing School. International Journal of Africa Nursing Sciences, 14, 100293. https://doi.org/10.1016/j.ijans.2021.100293.

Crismono, P. C. (2017). Pengaruh Outdoor Learning Terhadap Kemampuan Berpikir Kritis Matematis Siswa The Influence of Outdoor Learning On The Mathematical Critical Thinking Skills Of Students. Junal Pendidikan Matematika Dan Sains, 4(2), 106-113. https://doi.org/10.21831/jpms.v5i2.15482.

Farisi, A., Hamid, A., \& Melvina. (2017). Pengaruh Model Pembelajaran Problem Based Learning terhadap Kemampuan Berpikir Kritis dalam Meningkatkan Hasil Belajar Ssiswa pada Konsep Suhu dan Kalor. Jurnal Ilmiah Mahasiswa, 2(3), 283-287.

Febrina, D. A., \& Airlanda, G. S. (2020). Meta Analisis Pengaruh Problem Based Learning Terhadap Keterampilan Berpikir Kritis Di Sekolah Dasar. Jurnal Ilmiah Wahana Pendidikan, 6(4), 564-572. https://doi.org/10.5281/zenodo.4297499.

Firdaus, A., Nisa, L. C., \& Nadhifah, N. (2019). Kemampuan Berpikir Kritis Siswa pada Materi Barisan dan Deret Berdasarkan Gaya Berpikir. Jurnal, 10(1), 68-77. https://doi.org/10.15294/kreano.v10i1.17822.

Halidayanti, I. N. (2016). Penerapan Model Pembelajaran Problem Based Learning (PBL) Untuk Meningkatkan Aktivitas dan Hasil Belajar Siswa Kelas IV Pada Mata Pelajaran IPS Pokok Bahasan Kegiatan Ekonomi dalam Memanfaatkan Sumber Daya Alam Pada Siswa Kelas IV SDN Bintoro 02.

HS, E. F. H., Khaedar, M., \& Asriati. (2019). Peningkatan Hasil Belajar IPS Melalui Model Problem Based Learning (PBL) Pada Siswa Kelas IV SD Inpres Borong Jambu II Kota Makassar. Celebes Education Review, 1(1), 59-69. https://doi.org/10.37541/cer.v1i2.550.

Ihsan, M. S., Ramdani, A., \& Hadisaputra, S. (2019). Efektivitas Model Blended Learning Dalam Pembelajaran Kimia Untuk Meningkatkan Kemampuan Berpikir Kritis Peserta Didik. Jurnal Pijar Mipa, 14(2), 84-87. https://doi.org/10.29303/jpm.v14i2.1238.

Ikhsan, M., Munzir, S., \& Fitria, L. (2017). Kemampuan Berpikir Kritis dan Metakognisi Siswa dalam Menyelesaikan Masalah Matematika melalui Pendekatan Problem Solving. AKSIOMA: Jurnal Program Studi Pendidikan Matematika, 6(2), 234. https://doi.org/10.24127/ajpm.v6i2.991.

Kartikasari, I., Nugroho, A., \& Muslim, A. H. (2021). Penerapan Model PBL Untuk Meningkatkan Kemampuan Berpikir Kritis Siswa Pada Kelas IV Sekolah Dasar. Jurnal Gentala Pendidikan Dasar, 6(1), 44-56. https://doi.org/10.22437/gentala.v6i1.10124.

Kristiana, T. F., \& Radia, E. H. (2021). Meta Analisis Penerapan Model Problem Based Learning Dalam Meningkatkan Hasil Belajar IPA Siswa Sekolah Dasar. Jurnal Basicedu, 5(2), 818-826. https://doi.org/10.31004/basicedu.v5i2.828.

Lidyawati, Gani, A., \& Khaldun, I. (2017). Penerapan Model Problem Based Learning Untuk Meningkatkan hasil Belajar Dan Keterampilan Berpikir Kritis Peserta Didik Pada Materi Larutan Penyangga. Jurnal Pendidikan Sains Indonesia (Indonesian Journal of Science Education), 5(1), 140-146. https://doi.org/10.24815/jpsi.v5i1.16552.

Lisbiyaningrum, I., \& Wulandari, W. (2019). Penerapan Problem Based Learning Dalam Pembelajaran Tematik Integratif Untuk Meningkatkan Kemampuan Berpikir Kritis Siswa Kelas III Sekolah Dasar. Elementary School: Jurnal Pendidikan Dan Pembelajaran Ke-SD-An, 6(2), 161-168. https://doi.org/10.31316/esjurnal.v6i2.276.

Mulyadin. (2016). Implementasi Kebijakan Pembelajaran Tematik Terpadu Kurikulum 2013 di SDN Kauman 1 Malang dan SD Muhammadiyah 1 Malang. Jurnal Pendidikan Edutama, 3(2), 31-48. https://doi.org/10.30734/jpe.v3i2.35.

Ningsih, P. R., Hidayat, A., \& Kusairi, S. (2018). Penerapan problem based learning untuk meningkatkan kemampuan berpikir kritis dan hasil belajar siswa kelas III. Jurnal Pendidikan: Teori, Penelitian, Dan Pengembangan, 3(12), 1587-1593. https://doi.org/10.17977/jptpp.v3i12.11799.

Novika Auliyana, S., Akbar, S., \& Yuniastuti. (2018). Penerapan Pembelajaran Tematik Terpadu di Sekolah Dasar. Jurnal Pendidikan: Teori, Penelitian, Dan Pengembangan, 3(12), 1572-1582. https://doi.org/10.17977/jptpp.v3i12.11796.

Pangesti, W., \& Radia, E. H. (2021). Meta Analisis Pengaruh Model Pembelajaran Discovery Learning Terhadap Hasil Belajar IPA Siswa Sekolah Dasar. Elementary School, 8(2), $281 \quad$ - 286. https://doi.org/10.31316/esjurnal.v8i2.1313.

Persada, Y. I., Djatmika, E. T., \& Degeng, I. N. S. (2020). Pelaksanaan Pendekatan Scientific Dalam Pembelajaran Tematik. Jurnal Pendidikan: Teori, Penelitian, Dan Pengembangan, 5(1), 114-120. 
https://doi.org//10.17977/jptpp.v5i1.13151.

Pitt, V., Powis, D., Levett-Jones, T., \& Hunter, S. (2015). The influence of critical thinking skills on performance and progression in a pre-registration nursing program. Nurse Education Today, 35(1), 125-131. https://doi.org/10.1016/j.nedt.2014.08.006.

Polat, Ö., \& Aydın, E. (2020). The Effect of Mind Mapping on Young Children's Critical Thinking Skills. Thinking Skills and Creativity, 38,1-17. https://doi.org/10.1016/j.tsc.2020.100743.

Prasetyo, I. B. (2018). Penerapan Model Problem Based Learning (PBL) untuk Meningkatkan Proses dan Hasil Belajar Muatan PPKn pada Tema 8 Subtema 1. Jurnal Penelitian Dan Pengembangan Pendidikan, 2(2), 279-285. https://doi.org/10.23887/jppp.v2i2.15465.

Prayoga, A., \& Setyaningtyas, E. W. (2021). Keefektifan Model Pembelajaran Problem Based Learning dan Problem Solving Terhadap Kemampuan Berpikir Kritis Matematika Siswa Kelas V. Jurnal Cendekia: Jurnal Pendidikan Matematika, 5(3), 2652-2665. https://doi.org/10.31004/cendekia.v5i3.938.

Purnaningsih, W., Relmasira, S. C., \& Hardini, A. T. A. (2019). Upaya Peningkatan Kemampuan Berpikir Kritis dan Hasil Belajar Tematik Melalui Model Problem Based Learning (PBL) Kelas V SD. NATURALISTIC: Jurnal Kajian Penelitian Pendidikan Dan Pembelajaran, 367-375. https://doi.org/10.35568/naturalistic.v3i2.406.

Qurniati, D., Andayani, Y., \& Muntari. (2015). Peningkatan Keterampilan Berpikir Kritis Melalui Model Pembelajaran Discovery Learning. E-Journal Penelitian Pendidikan IPA, 1(2), 12-23. https://doi.org/10.29303/jppipa.v1i2.20.

Rahmatia, F. (2020). Pengaruh Model Pembelajaran Problem Based Learning Terhadap Kemampuan Berpikir Kritis di Sekolah Dasar. Jurnal Pendidikan Tambusai, 4(3), 2685-2692. https://doi.org/10.31004/jptam.v4i3.760.

Rosa, N. M., \& Pujiati, A. (2017). Pengaruh Model Pembelajaran Berbasis Masalah Terhadap Kemampuan Berpikir Kritis dan Kemampuan Berpikir Kreatif. Formatif: Jurnal Ilmiah Pendidikan MIPA, 6(3), 175-183. https://doi.org/10.30998/formatif.v6i3.990.

Saidah, N., Parmin, \& Dewi, N. R. (2014). Pengembangan LKS IPA Terpadu Berbasis Problem Based Learning Melalui Lesson Study Tema Ekosistem Dan Pelestarian Lingkungan. USEJ - Unnes Science Education Journal, 3(2). https://doi.org/10.15294/usej.v3i2.3357.

Saputro, O. A., \& Rayahu, T. S. (2020). Perbedaan Pengaruh Penerapan Model Pembelajaran Project Based Learning ( Pjbl) Dan Problem Based Learning ( Pbl ) Berbantuan Media Monopoli. Jurnal Imiah Pendidikan Dan Pembelajaran, 4(1), 185-193. https://doi.org/10.23887/jipp.v4i1.24719.

Sari, S. P., Koeswant, H. D., \& Giarti, S. (2019). Penerapan Model Pembelajaran Problem Based Learning Untuk Meningkatkan Keterampilan Berpikir Kritis Pada Muatan Matematika Kelas 4. Jurna Basicedu, 3(2), 378 - 386. https://doi.org/10.31004/basicedu.v3i2.15.

Seibert, S. A. (2020). Problem-based learning: A strategy to foster generation Z's critical thinking and perseverance. Teaching and Learning in Nursing, 000, 2-5. https://doi.org/10.1016/j.teln.2020.09.002.

Septiana, T. S., \& Kurniawan, M. R. (2018). Penerapan Model Problem Based Learning Untuk Meningkatkan Berpikir Kritis Siswa Kelas 5 Pada Mata Pelajaran PKN di SD Muhammadiyah Kauman Tahun 2016/2017. Jurnal Fundadikdas (Fundamental Pendidikan Dasar), 1(1), 94-105. https://doi.org/10.12928/fundadikdas.v1i1.74.

Sipayung, Y. W. S., \& Hutahaean, J. H. (2016). Pengaruh Model Pembelajaran Berbasis Masalah (Problem Based Learning) Terhadap Hasil Belajar Siswa Kelas X SMA Negeri 1 Tamalatea Kabupaten Jeneponto ( Studi pada Materi Pokok Reaksi Reduksi Oksidasi ). INPAFI (Inovasi Pembelajaran Fisika), 4(2), 94-102. https://doi.org/10.24114/inpafi.v4i2.5521.

Stephani, M. R. (2017). Stimulasi Kemampuan Berpikir Kritis melalui Pembelajaran Berbasis Masalah pada Pendidikan Jasmani. Jurnal Pendidikan Jasmani Dan Olahraga, 2(1), $16 \quad$ - 27. https://doi.org/10.17509/jpjo.v2i1.6397.

Suari. (2018). Penerapan Model Pembelajaran Problem Based Learning Untuk Meningkatkan Motivasi Belajar IPA. Jurnal Sekolah Ilmiah Dasar, 241-247. https://doi.org/http://dx.doi.org/10.23887/jisd.v2i3.16138.

Suci, D. W., Firman, F., \& Neviyarni, N. (2019). Peningkatan Keterampilan Berpikir Kritis Siswa Melalui Pendekatan Realistik di Sekolah Dasar. Jurnal Basicedu, 3(4), 2042-2049. https://doi.org/10.31004/basicedu.v3i4.229.

Sudarti, \& Putra, P. D. A. (2015). Real Life Video Evaluation Dengan Sistem E-Learning Untuk Meningkatkan Keterampilan Berpikir Kritis Mahasiswa. Jurnal Kependidikan: Penelitian Inovasi Pembelajaran, 45(1), 107696. https://doi.org/10.21831/jk.v45i1.7187

Suriana, Halim, A., \& Mursal. (2016). Penerapan Model Problem Based Learning (Pbl) Berbasis Eksperimen Untuk Meningkatkan Pemahaman Konsep USAha Dan Energi Ditinjau Dari Gaya Berpikir Siswa Di Man Rukoh Banda Aceh. Jurnal Pendidikan Sains Indonesia, 4(1), 123431. https://doi.org/10.24815/jpsi.v4i1.6591. 
Tapung, M., Maryani, E., \& Supriatna, N. (2018). Improving students' critical thinking skills in controlling social problems through the development of the emancipatory learning model for junior high school social studies in manggarai. Journal of Social Studies Education Research, 9(3), 162-176. https://doi.org/10.17499/jsser.23826.

Triana, D., Anggraito, Y. U., \& Ridlo, S. (2020). Effectiveness of environmental change learning tools based on STEM-PjBL towards 4C skills of students. Journal of Innovative Science Education, 9(2), 181-187. https://doi.org/10.15294/JISE.V8I3.34048.

Utama, K. H., \& Kristin, F. (2020). Meta-Analysis Pengaruh Model Pembelajaran Problem Based Learning (PBL) Terhadap Kemampuan Berpikir Kritis IPA Di Sekolah Dasar. Jurnal Basicedu, 4(4), 889-898. https://doi.org/10.31004/basicedu.v4i4.482.

Utami, D. (2019). Model Problem Based Learning (Pbl) Berbantuan Mediaaudio Visual Untuk Meningkatkan Keterampilan Berpikir Kritis Pada Siswa Kelas 5 Sekolah Dasar. MAJU, 6(1). https://doi.org/10.24903/pm.v5i1.461.

Utami, N. B., Kristin, F., \& Anugraheni, I. (2019). Penerapan Model Pembelajaran Problem Based Learning Untuk Meningkatkan Hasil Belajar Matematika Dan Berfikir Kritis Siswa Kelas 4 SD. Eduma: Mathematics Education Learning and Teaching, 8(1), 33-40. https://doi.org/10.22373/pjp.v8i1.5048.

Utami, R. A., \& Giarti, S. (2020). Efektivitas Model Pembelajaran Problem Based Learning (PBL) Dan Discovery Learning Ditinjau Dari Keterampilan Berpikir Kritis Siswa Kelas 5 SD. PeTeKa, 3(1), 1-8. https://doi.org/10.31604/ptk.v3i1.1-8.

Wati, L., Gani, A., \& Khaldun, I. (2017). Penerapan Model Problem Based Learning untuk Meningkatkan Hasil Belajar dan Ketrampilan Berpikir Kritis Peserta Didik pada materi larutan Penyangga. Jurnal Pendidikan Sains Indonesia (Indonesian Journal of Science Education), 5(1), 140-146.

Wedekaningsih, A., Koeswanti, H. D., \& Giarti, S. (2019). Penerapan Model Pembelajaran Discovery Learning Untuk Meningkatkan Keterampilan Berpikir Kritis Dan Hasil Belajar Matematika Peserta Didik. Jurnal Basicedu, 3(1), 21 - 26. https://doi.org/10.31004/basicedu.v3i1.73. 